\title{
Physical-Chemical and Mechanical Characterization of the Bast Fibers of Triumfetta cordifolia A.Rich. from the Equatorial Region of Cameroon
}

\author{
Armel Edwige Mewoli1,2*, César Segovia ${ }^{3}$, Fabien Betene Ebanda1,2, Atangana Ateba1,2, \\ Pierre Marcel Anicet Noah ${ }^{1,2}$, Benoit Ndiwe ${ }^{4}$, Abel Emmanuel Njom ${ }^{5}$ \\ ${ }^{1}$ Department of Mechanical Engineering, ENSET, University of Douala, Douala, Cameroon \\ ${ }^{2}$ Laboratory of Mechanics, University of Douala, Cameroon, Douala, Cameroon \\ ${ }^{3}$ CETELOR, University of Lorraine, CETELOR/27 rue Philippe SEGUIN, Epinal, France \\ ${ }^{4}$ Laboratory of Mechanics, Materials, and Modelization, National School of AGRO-Industrial Sciences (ENSAI) Physics \\ Application and Engineering, Ngaoundere University, Ngaoundere, Cameroon \\ ${ }^{5}$ Laboratory of Mechanics, Materials, Structures and Integrated Manufacturing, National Advanced School of Engineering, \\ University of Yaounde 1, Yaounde, Cameroon \\ Email: ^armel.mewoli@ensetdouala.net, mewoliarmel@yahoo.fr
}

How to cite this paper: Mewoli, A.E., Segovia, C., Betene Ebanda, F., Ateba, A., Noah, P.M.A., Ndiwe, B. and Njom, A.E. (2020) Physical-Chemical and Mechanical Characterization of the Bast Fibers of Triumfetta cordifolia A.Rich. from the Equatorial Region of Cameroon. Journal of Minerals and Materials Characterization and Engineering, 8, 163-176.

https://doi.org/10.4236/jmmce.2020.84011

Received: April 30, 2020

Accepted: May 31, 2020

Published: June 3, 2020

Copyright $\odot 2020$ by author(s) and Scientific Research Publishing Inc. This work is licensed under the Creative Commons Attribution International License (CC BY 4.0).

http://creativecommons.org/licenses/by/4.0/

\begin{abstract}
The project consists in the implementation of a biocomposite based on tannin resin and natural rubber matrices with the bast fibres of Triumfetta cordifolia A.Rich. "Okong" from the equatorial region of Cameroon as reinforcement. A study of this still little known fibre is necessary. This paper evaluates the physico-chemical and mechanical characteristics of the fibers. The fibers are extracted by us. A series of experiments is conducted for this purpose: morphological observation with a scanning electron microscope (SEM); density evaluation with a helium pycnometer; absorption rate evaluation according to the protocol available in the literature, Fourier Transform Infrared Spectrometry (FT-IR), chemical composition evaluation according to ASTM 1972 and ASTM 1977 standards, thermogravimetric analysis (TGA) and tensile tests on fiber bundles according to NF T25-501-3. The results show that the fiber is made up of several elementary fibers with oval cross-sections. A density of $1.477 \mathrm{~g} / \mathrm{cm}^{3}$ close to that of hemp. These fibers have a water absorption rate of $342.5 \%$, which correlates with the presence of free hydroxyl functional groups obtained from the spectrometry study (FT-IR). Chemical analysis reveals that the fiber is made up of celluloses (44.4\%), hemicelluloses (30.8\%), lignins (18.9\%), pectins (3.3\%), waxes $(0.5 \%)$ and minerals $(2.1 \%)$. In addition, we learn that the fibers studied dehydrate at $11.49 \%$, showing a notable thermal stability around $235^{\circ} \mathrm{C}$ with a peak thermal decomposition of
\end{abstract}


cellulose located at $420^{\circ} \mathrm{C}$. In terms of mechanical behaviour, the results reveal that the fibers offer a Young's modulus in traction of $12.4 \pm 6.9 \mathrm{GPa}$, a tensile strength of $526 \pm 128 \mathrm{MPa}$ and an elongation at break of $2.25 \%$. The information thus obtained makes it possible to place these fibers in the same fiber group as flax and jute. They could therefore be used for the same types of applications. They also inform us that these fibers can withstand the temperatures of composite shaping by thermocompression.

\section{Keywords}

Triumfetta cordifolia Fibers, Morphology, Chemical Analysis, Thermal Degradation, Mechanical Behavior

\section{Introduction}

The selective choice of a reinforcing fiber is of the utmost importance and requires knowledge of all the physico-chemical, mechanical and thermal properties in order to produce good quality composite materials. To this end, natural fibers are governed by a set of parameters, including: chemical composition, crystallinity index (CrI) of the cellulose, microfibrillar angle (MFA), good length/diameter (L/D) ratio of the fiber, good tensile strength, good elongation capacity and low sensitivity to temperature and humidity variations [1].

In order to develop natural composites based on plant resins, reinforced with bast fibers of Triumfetta cordifolia A.Rich. (TC) harvested in Cameroon, knowledge of these parameters is essential for the overall performance of the composite.

To date, Senwitz et al. [2], have carried out a characterisation study of TC fibers and the results reveal that the property values obtained from TC fibers harvested in the northern zone of Angola are comparable to those of commercial jute, flax, hemp and kenaf fibers. They also reveal the potential required as a reinforcement for composites. Indeed, these results show an average Young's modulus of (12.5 - 53.4 GPa), tensile strength of TC fibers (209.1 - 916.3 MPa) and $(1.56 \%-1.56 \%)$ deformation at break. They also have a density of (1.16 $\left.1.41 \mathrm{~g} / \mathrm{cm}^{3}\right)$, a microfibril angle of $\left(7^{\circ} \pm 5^{\circ}\right)$, and finally a chemical composition consisting of Holocellulose (72.26\% - 87.90\%), lignin (9.90\% - 13.67\%), and extract content $(0.70 \%-3.10 \%)$.

In view of these encouraging properties, develop biocomposites based on plant resins with TC bast fiber reinforcements. In the hypothesis of the use of this fiber, in the reinforcement of plant matrices such as tannin extracted from Aningré or Abam (Aningeria superba) and natural rubber latex (NR) derived from Brazilian rubber grown in Cameroon, shaping requires knowledge of the degradation temperatures of the fibers [3] [4]. It is therefore imperative that the degradation profile and in particular the thermal stability of the fibers be known before their use in composite applications [5]. For the moment, this information 
is available for our fiber. It is known that, the composites with vegetable fiber reinforcements are shaped in the temperature range between $200^{\circ} \mathrm{C}$ and $250^{\circ} \mathrm{C}$ [6] [7] [8]. Also, most of the specimens with vegetable fiber reinforced vulcanized natural rubber and tannin matrices are usually processed by thermocompression [9]. It is therefore imperative to complete the knowledge of the fiber.

After all, the characteristics of plant fibers vary from one geographical area to another, so it is advisable to repeat the determination of the characteristics of the fiber already available in the literature.

In this article, we present the fiber extraction procedure. Microscopic examination was performed using a Hitachi 3000 scanning electron microscope (SEM). The pycnometer was used to evaluate the density of the fibers. Chemical analysis was performed to determine the content of cellulose, hemicellulose in lignin, pectins in waxes and minerals. Moisture content was calculated. By means of infrared spectroscopy (FT-IR) the structural functional groups were identified. The thermal behaviour of the fiber was evaluated by thermogravimetric analysis (TGA). Finally, the tensile properties of fiber bundles were measured using a FAVIMAT+ machine.

\section{Materials and Methods}

\subsection{Extraction of Triumfetta cordifolia Fibers}

The raw material Figure 1(a) and Figure 1(b) is collected in Yaounde in the central region of Cameroon, in mid-December, when the ambient temperature is around $30^{\circ} \mathrm{C}$. The raw material is collected in the center of the country. For extraction of TC bark (Figure 1(c) and Figure 1(d), the fiber is soaked in stagnant water [10] for six (06) weeks (Figure 1(e)). They are then hand washed (Figure $1(\mathrm{f})$ and Figure $1(\mathrm{~g})$ ) to remove mucilage, rinsed with water and dried in the shade. These operations are carried out at a temperature between $27^{\circ} \mathrm{C}$ and $30^{\circ} \mathrm{C}$. After this extraction process, the extracted fibers are shown in the figure (see Figure $1(\mathrm{~h})$ ).

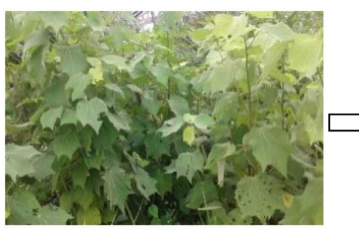

(a)

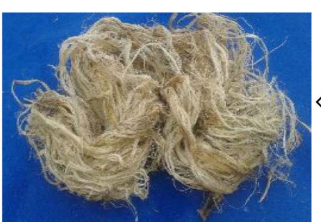

(h)

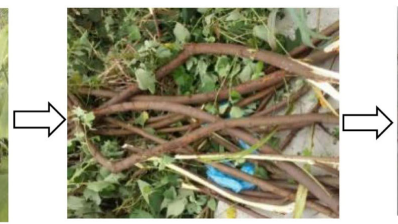

(b)

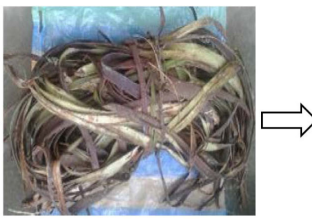

(c)

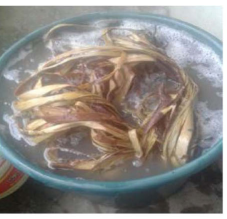

(d)

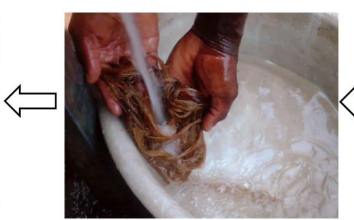

(g)

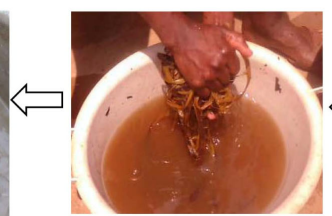

(f)

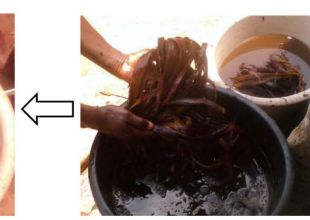

(e)

Figure 1. Some pictures of the TC fiber extraction process: (a) TC plant, (b) TC stems harvested, (c) TC bark, (d) Soaked TC bark, (e) TC bark after 6 weeks, (f) Washing of TC bark, (g) Rinsing of TC, (h) TC fibers extracted. 


\subsection{Scanning Electron Microscopy Analysis}

The microscopic examination and the calculation of the effective cross-section are performed using Hitachi 3000 Scanning Electron Microscopy (SEM). In agreement A batch of staple fibers was mechanically opened on the Laroche opener at $1200 \mathrm{rpm}$. A type of process used in pre-treatment for composite/non-woven reinforcement type applications. The fibers are separated manually, aligned to have a homogeneous parallelization of the fibers and then introduced into the sample holder of the scanning electron microscope after metallization. All images were taken at an accelerating voltage of $15 \mathrm{kV}$. Image Pro Premier ${ }^{\circledR}$ software is then used to determine the fiber dimensions.

\subsection{Density Measurements}

The fibers were previously dried in the oven at $60^{\circ} \mathrm{C}$ for 24 hours and cooled in a desiccator at room temperature. The density of each sample is determined by measuring the dry fiber weight determined with a $0.0001 \mathrm{~g}$ precision balance and then introduced into the container of the Quantchrome Helium Pycnometer MVP-6DC Pycnometer Instruments. The operating principle of the helium pycnometer is based on the gas law [11], defined by Equation (1). The volume of the fiber is determined by measuring the pressure variation experienced by the fluid due to the displacement of the fluid in constant volume by the test sample. This method is in accordance with [12].

$$
\rho=\frac{W_{f}}{V_{p}} \text { where } V_{p}=V_{c}-\left(V_{r}\left(\frac{P_{1}}{P_{2}}\right)-1\right)
$$

where $\rho$ is the density $\left(\mathrm{g} / \mathrm{cm}^{3}\right), V_{f}$ is the fiber weight $(\mathrm{g}), V_{p}$ is the sample volume $\left(\mathrm{cm}^{3}\right), V_{c}$ is the sample orifice volume $\left(\mathrm{cm}^{3}\right), V_{r}$ is the reference volume $\left(\mathrm{cm}^{3}\right), P_{1}$ is the pressure measured after pressurizing the reference volume $\left(V_{r}\right)(\mathrm{PSI}), P_{2}$ is the pressure measured after including the cell volume $\left(V_{c}\right)$ (PSI).

\subsection{Water Absorption}

The TC fiber water absorption test was performed according to the method of [13]. Seven samples were prepared and the mean percent water absorption was calculated using Equation (2). The samples were first weighed as $M_{0}$ and then immersed in fresh water for 24 hours at room temperature. After 24 hours of immersion, the samples were reweighed as $M_{1}$.

$$
\text { Abs }=\frac{M_{1}-M_{0}}{M_{0}} \times 100 \%
$$

\subsection{FTIR-ATR Spectrometry}

A Fourier Transform Infrared (FTIR) analysis is performed using a Shimadzu IRAffinity-1 CE Shimadzu instrument equipped with a diamond crystal operating in ATR mode. The infrared spectrum is recorded from 500 to $4000 \mathrm{~cm}^{-1}$ by accumulation of 32 scans with a resolution of $4 \mathrm{~cm}^{-1}$. 


\subsection{Chemical Characterization}

The determination of the content of cellulose, hemicelluloses, lignin, pectin and waxes is carried out in accordance with ASTM 1972 and ASTM 1977. The method used is a method by successive extraction of the components of the fibrous material by solvents from a mass of approximately $2 \mathrm{~g}$ of ground and dried fiber. The first extraction the alcohol-toluene mixture which will dissolve the waxes and fats and then a second extraction is carried out with hot water at $90^{\circ} \mathrm{C}$ which will allow the determination of the quantity of mineral salts as well as the low percentages of tannins, starch and polysaccharides. Then a third extraction to separate the pectins is carried out with an aqueous solution of ammonium oxalate extraction. Then the lignins are dissolved by a solution of sodium chlorite and glacial acetic acid. Finally, the hemicelluloses are solubilized by a solution of potassium hydroxide and then by a solution of soda which, by elimination, will make it possible to determine the percentage of cellulose and hemicellulose. The values obtained are the average of three repetitions of the rate of the constituents of the fibers.

\subsection{Thermogravimetric Analysis (TGA)}

The thermogravimetric analysis is performed on an analyzer (TGA) using the NETZSCH STA 449F3 Jupiter (Germany) under constant air from $25^{\circ} \mathrm{C}$ to $700^{\circ} \mathrm{C}$ at a heating rate of $10^{\circ} \mathrm{C} / \mathrm{min}$. About $10 \mathrm{mg}$ of the sample was used.

\subsection{Tensile Strength}

The test specimens were first separated manually and stored in a conditioning chamber at a controlled temperature of $20^{\circ} \mathrm{C} \pm 1.5^{\circ} \mathrm{C}$ and a relative humidity of $60 \% \pm 1 \%$ for 24 hours. Tensile tests on fiber bundles were carried out on a FAVIMAT+ machine. For this purpose, 44 fibers were tested at a speed of $5 \mathrm{mn} / \mathrm{min}$ in accordance with the NF T25-501-3 standard. The tests were carried out using a $3200 \mathrm{cN}$ force sensor, the holding length was $10 \mathrm{~mm}$. The effective cross-section was calculated from a scanning electron microscopy (SEM), using a Hitachi 3000 instrument, in accordance with [14].

\section{Results and Discussions}

\subsection{Scanning Electron Microscopy Analysis}

Like flax and hemp, TC fibers are located at the periphery of the stem. Figure 2(a) and Figure 2(b) show the morphology of the TC fiber. It was possible to separate the fibers from each other and thus obtain the unitary fiber (Figure $2(a))$ by treatment one by one with a Laroche opener.

Figure 1(a) shows the cross-section of the TC fiber. This view shows that the structure of a TC fiber is made up of several elementary fibers (also called unit fibers) superimposed not only on the cross-section but also on the length of the fibers. They are firmly bonded together by pectin and other non-cellulosic compounds that give strength to the entire bundle [15]. In addition, Figure 2(a) 


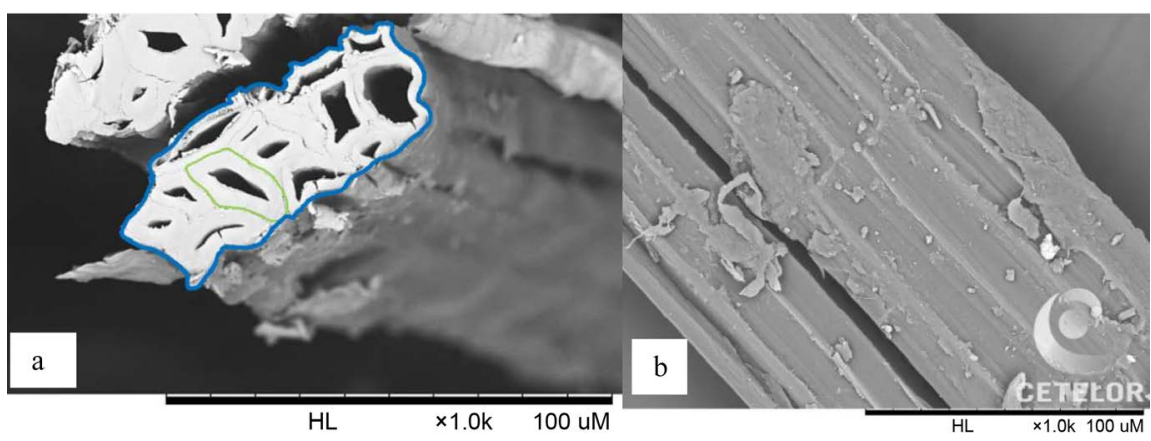

Figure 2. Bast TC fibers: (a) in blue a technical fiber, (b) in green a unitary fiber.

shows the cross-section of the lumen structure. This lumen is oval in shape, this shape and large aperture could be due to the efforts applied during the preparation of the fibers. Indeed, the fibers were separated (opened) with the Laroche opener. Figure 2(b) is a longitudinal view of the TC fiber. It shows that there are impurities on the surface, and this structure has many burrs, which is due to the absence of surface treatments. However, the strength of the bundle structure is much lower than that of the elementary cell (see Table 4).

\subsection{Density}

The density of TC fiber is low at $1.477 \pm 0.016 \mathrm{~g} / \mathrm{cm}^{3}$, but close to $\left(1.41 \mathrm{~g} / \mathrm{cm}^{3}\right)$ compared to the same species [2]. Moreover, it should be noted that it is similar to that of flax fibers and $\left(1.50 \mathrm{~g} / \mathrm{cm}^{3}\right)$ of hemp fibers $\left(1.47 \mathrm{~g} / \mathrm{cm}^{3}\right)$ respectively [16] [17] and therefore TC fiber can be used in the same applications as the latter.

\subsection{Water Absorption}

Water absorption by TC fibers is high at $342.3 \%$. This highly hydrophilic character is also attributed to the presence of hemicelluloses [18], but also to the high group content of free hydroxyl groups [13], responsible for moisture sorption (see IR-spectrum in Figure 3) and affects the physical and mechanical properties of our fibers [18]. Also the high porosity observed on the microstructure (Figure 1). According to [19], this character leads to drops in stiffness and the appearance of cracks within the composite. Nevertheless, it should be noted that this disadvantage could still be improved by a surface treatment.

\subsection{FTIR-ATR Spectrometry}

The spectral analysis of the TC fibers obtained gives us the FTIR-ATR spectrum (Figure 3).

The infrared spectrum obtained above shows the positions of the well-defined remarkable peaks: 3333, 2917, 1728, 1605, 1506, 1425, 1315, 1031 and $662 \mathrm{~cm}^{-1}$ identified in Table 1. The first peak at $3330 \mathrm{~cm}^{-1}$ represents the hydrogen $(\mathrm{O}-\mathrm{H})$ bonds of the inter and intramolecular network of cellulose, as well as the free hydroxyl groups of hemicellulose [20]. Moreover, Célino et al. [16] have observed 


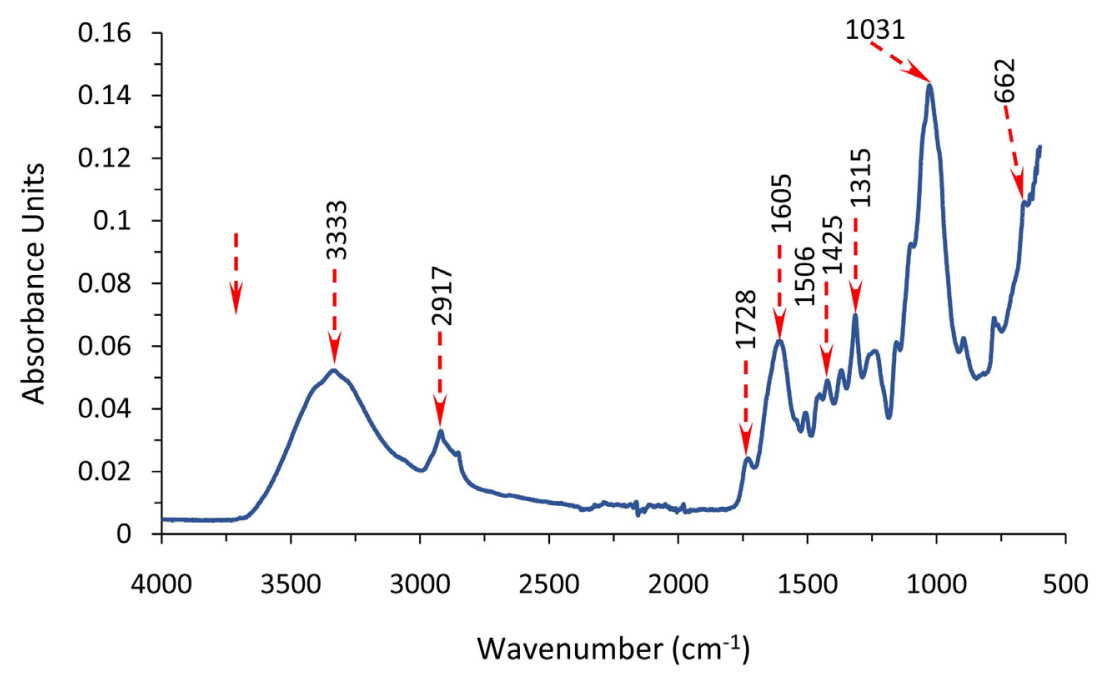

Figure 3. ATR-FTIR spectrum of TC fibers.

Table 1. Characteristic positions of the FTIR bands of TC fiber and their assignments.

\begin{tabular}{clc}
\hline $\begin{array}{c}\text { Wavenumber } \\
\left(\mathrm{cm}^{-1}\right)\end{array}$ & \multicolumn{1}{c}{ Assignments } & References \\
\hline 3333 & OH stretching (cellulose) & {$[20]$} \\
2917 & C-H stretching (cellulose-hemicellulose) & {$[16][20][21][22]$} \\
1728 & C=O stretching vibration (pectins, waxes et hemicellulose) & {$[7][21][23]$} \\
1605 & Aromatic ring (lignin) & {$[16][22]$} \\
1506 & C=C aromatic symmetrical stretching (lignin) & {$[20][21][22]$} \\
1425 & Vibration of the carboxyl bond characteristic of pectins & {$[24][25]$} \\
1315 & CH wagging (cellulose and hemicellulose) C-O stretching & {$[16]$} \\
1234 & vibration in ester & Acetyl groups (hemicellulose) \\
1031 & C-O stretching ring (cellulose and hemicellulose) & {$[16]$} \\
662 & C-OH out of plane bending (cellulose) & {$[25]$} \\
\hline
\end{tabular}

that this absorption band is characteristic of the presence of liquid water more or less bound to the polymeric network that constitutes the natural fibers. The second peak located at $2917 \mathrm{~cm}^{-1}$ represents the $(-\mathrm{CH})$ group present in hemicellulose and cellulose [16] [21] [22] [23]. However, we observe an evidence by the decrease of the signal of the characteristic peak at $1728 \mathrm{~cm}^{-1}$ which corresponds to symmetrical elongation of ester group ( $\mathrm{C}=\mathrm{O}$ of carboxylic acids) present in pectins, waxes and acetyl groups present in hemicelluloses [7] [23]. Also the absorption of this peak confirms the hydrophilic nature of the natural fiber [21]. The region of the spectrum in the band between $1506 \mathrm{~cm}^{-1}$ and 1605 $\mathrm{cm}^{-1}$ is characteristic of the symmetrical aromatic $(\mathrm{C}=\mathrm{C})$ elongation present in lignin. The observable peak around $1315 \mathrm{~cm}^{-1}$ is characteristic of the vibration of the $-\mathrm{CH}$ bond and the aromatic - $\mathrm{CO}$ group present in polysaccharides. From there, at $1031 \mathrm{~cm}^{-1}$, peaks corresponding to stretching bonds of the $\mathrm{C}-\mathrm{O}$ ring are 
found. These bonds are characteristic of cellulose and hemicellulose [16]. Finally, the characteristic peak at $662 \mathrm{~cm}^{-1}$ is attributed to cellulose [20] [25]. These results show that TC fiber is composed of cellulose, hemicellulose, lignin, pectins, waxes and polysaccharides. It is therefore similar to known plant fibers such as jute, sisal, flax and hemp [22] [26].

\subsection{Chemical Composition}

The chemical composition of the TC fiber and the values of other vegetable fibers are given in Table 2. In contrast to the work of Senwitz et al. [2], which gives the holocellulose $(72.26 \%-87.90 \%)$ and extract content $(0.70 \%-3.10 \%)$ contents, this chemical analysis goes as far as to dissociate the cellulose, hemicellulose, pectins, waxes and minerals in terms of content. It appears that TC fiber contains $44.4 \%$ cellulose, thus less than hemp or flax but close to kenaf, jute and coconut fiber in the literature [27] [28] [29]. This content also indicates that its fibers could find very good applications in composites and textiles. On the other hand, the $30.8 \%$ hemicellulose content is higher compared to conventional fibers [27] [28] [29] [30]. This is due to its highly hydrophilic nature, which is responsible for the absorption of water due to the presence of free hydroxyl groups in its structure [18] [19] [20]. The percentage of lignin (18.9\%) is similar to that of flax and kenaf [27] but it is high compared to the work of Senwitz et al., [2]. These studies also note that the high lignin and hemicellulose content increases with retting time. Consequently, the considerable amount of pectins (3.3\%) and hemicellulose that is not removed during retting results in a significant reduction in the stiffness and strength of TC fibers [2]. Finally, TC fibers have $(2.1 \%)$ minerals and also a very low wax content $(0.5 \%)$.

\subsection{Thermogravimetric Analysis (TGA)}

The results of the thermogravimetric analysis (TGA) of the fiber under study give us the TG-DTG curves in Figure 4.

Table 2. Chemical composition of lignocellulosic fibers.

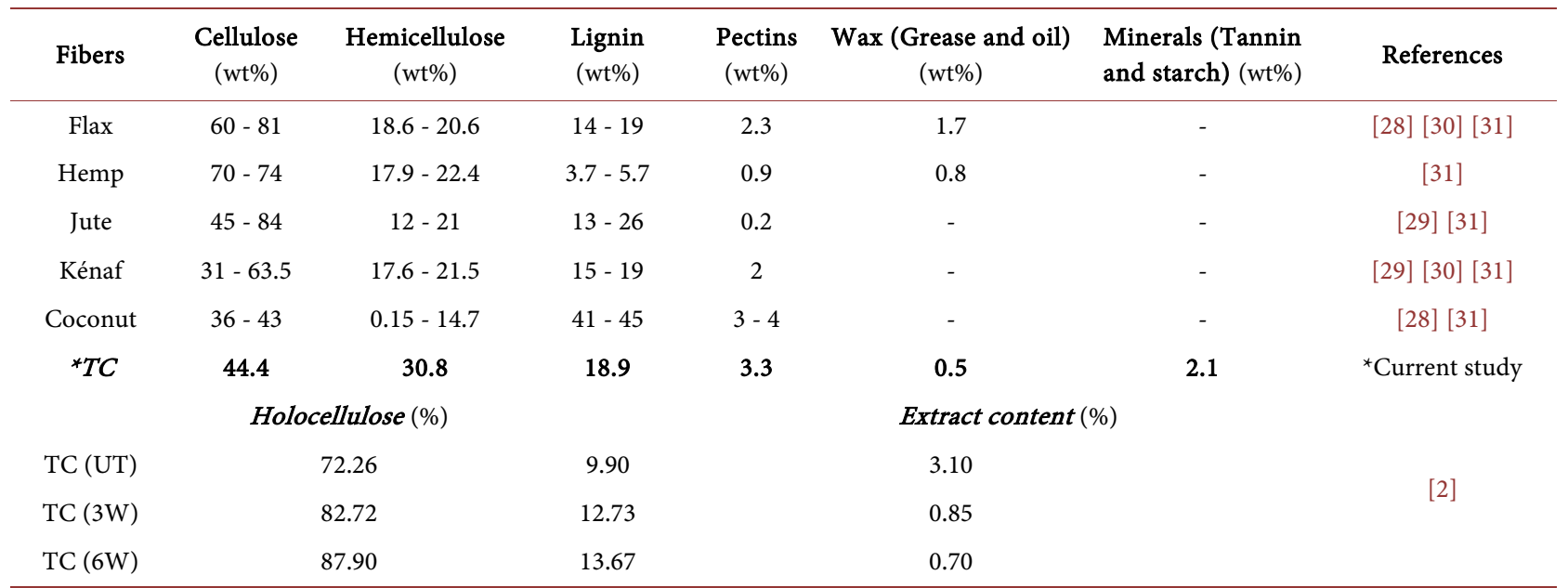

${ }^{*} T C \quad\left({ }^{*}\right)$ Current study; UT, untreated; $3 \mathrm{~W}$, fibers retted for three weeks; $6 \mathrm{~W}$, fibers retted for six weeks. 


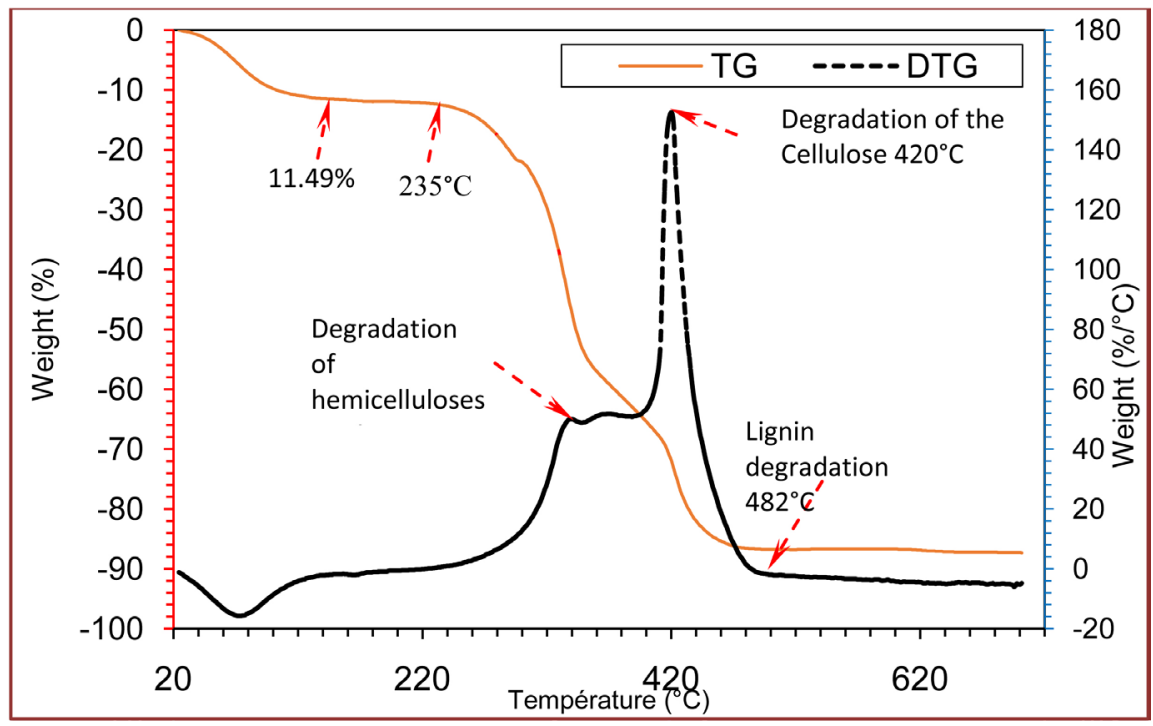

Figure 4. TG -DTG curves of TC fibers.

These curves are similar to those obtained for linen, jute, banana and hemp [7] [13] [32] [33]. They show three main regions of mass loss: An initial mass loss, observed in the temperature range $75^{\circ} \mathrm{C}-144^{\circ} \mathrm{C}$, of about $11.49 \%$, which is mainly attributed to fiber dehydration [17]. This mass loss stabilizes at $235^{\circ} \mathrm{C}$ and is the locus of thermal stability of the fiber [33]. A further loss of mass will occur above $235^{\circ} \mathrm{C}$ (46.02\%), due to the decomposition of the less thermally stable elements such as non-structural hemicelluloses [21] [32] [34], fats and waxes [35]. The inflection point observed at about $336^{\circ} \mathrm{C}$, (loss of mass of about $43 \%$ ), would correspond to the destruction of part of the constituents (cellulose in particular and the oxidative degradation of carbonized residues) [33].

The DTG curve of the TC fiber shows a peak at $420^{\circ} \mathrm{C}$ (mass loss of $72 \%$ ) which is due to the thermal decomposition of the cellulose [7] [33]. According to [21] [22], lignin is more heat resistant and decomposes last. This decomposition is observed in the $420^{\circ} \mathrm{C}-482^{\circ} \mathrm{C}$ region. Above $482^{\circ} \mathrm{C}$, mass loss becomes very slow and a stable residue is formed. A residue of $12.69 \%$ of the TC fiber remains after heating to $700^{\circ} \mathrm{C}$. Table 3 compares the degradation characteristics of the fiber under study with those of other known plant fibers.

It can be observed that $\mathrm{TC}$ has an important residue compared to other vegetable fibers except banana fibers, which would confirm a better temperature resistance.

\subsection{Tensile Strength of TC fiber}

The tensile tests reported in Figure 5(a) show that the TC fiber is a fiber with low elasticity and its mode of rupture qualifies it as brittle.

Figures 5(b)-(d) and Table 4 through the associated values show that these fibers have low mechanical properties compared to those of the same plant from the work of Senwitz et al. [2] except for elongation they are the most extensible. 
Table 3. Thermal behaviour of vegetals fibers. ${ }^{\star}\left(700^{\circ} \mathrm{C}\right)$.

\begin{tabular}{cccccc}
\hline \multirow{2}{*}{ Fibers } & \multicolumn{2}{c}{ Temperature degradation $\left({ }^{\circ} \mathrm{C}\right)$} & $\begin{array}{c}\text { Degradation }(\%) \\
\text { of Cellulose }\end{array}$ & $\begin{array}{c}\text { Residue \% at } \\
800^{\circ} \mathrm{C}\end{array}$ & References \\
\cline { 2 - 5 } & Initial & Final & 72 & $12.69^{*}$ & Current study \\
\hline TC & 235 & 420 & 72 & 5.0 & {$[7][33]$} \\
Sisal & 220 & 415 & 81.96 & 10.49 & {$[36]$} \\
Kenaf & 233.5 & 442.2 & 78.88 & 11.83 & {$[36]$} \\
Jute & 229.5 & 442.0 & 76.36 & 10.9 & {$[13]$} \\
Roselle & 220 & 400 & 51.5 & 24.3 & {$[37]$} \\
Banana & 263 & 374 & &
\end{tabular}

Table 4. Mechanical properties Triumfetta cordifolia compared to other plant fibers.

\begin{tabular}{ccccccc}
\hline Fibers & $\rho\left(\mathrm{g} / \mathrm{cm}^{3}\right)$ & Area $\left(\mu \mathrm{m}^{2}\right)$ & $\sigma(\mathrm{Mpa})$ & $\mathrm{E}(\mathrm{Gpa})$ & $\boldsymbol{\varepsilon}(\%)$ & References \\
\hline Cotton & 1.55 & - & $300-600$ & $5.50-12.6$ & & {$[30][31]$} \\
Flax & 1.50 & - & $345-1035$ & 27.6 & $2.7-3.2$ & {$[30][31]$} \\
Jute & 1.50 & - & $187-773$ & $10-26.5$ & $1.5-3.1$ & {$[30][31]$} \\
RC & 0.947 & - & $150-1738$ & $2.3-17$ & $10.9-53$ & {$[38]$} \\
NA & - & - & 61.64 & 6.043 & 0.0102 & {$[39]$} \\
TC (UT) & 1.16 & - & $209.1 \pm 64.1$ & $12.5 \pm 3.3$ & $2.55 \pm 0.61$ & {$[2]$} \\
TC (3W) & 1.26 & - & $916.3 \pm 370.3$ & $53.4 \pm 10.3$ & $1.75 \pm 0.62$ & {$[2]$} \\
TC (6W) & 1.41 & - & $890.6 \pm 293.6$ & $59.8 \pm 9.7$ & $1.56 \pm 0.43$ & {$[2]$} \\
$* T C$ & 1.477 & 4437 & $526 \pm 128$ & $12.4 \pm 6.9$ & 2.25 & $\left({ }^{*}\right)$ Current study \\
\hline
\end{tabular}
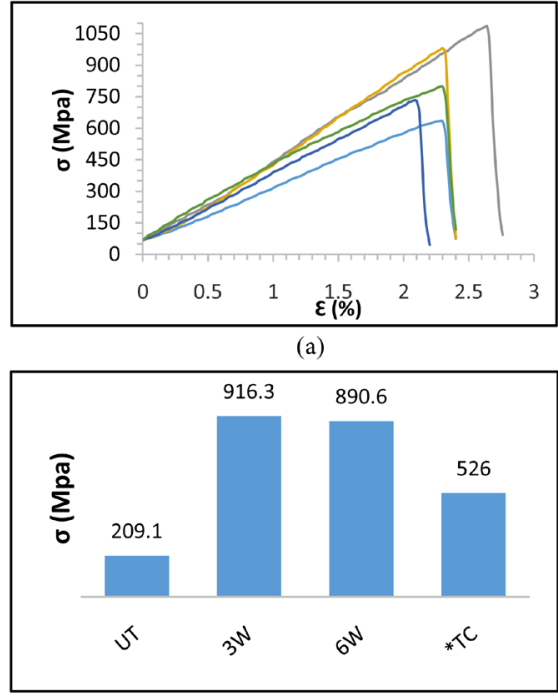

(c)
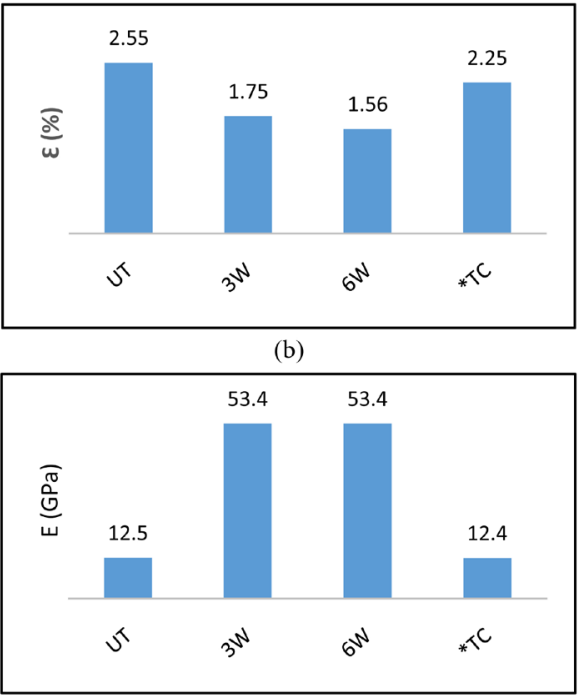

(d)

Figure 5. Tensile behaviour of TC fibers: (a) Stress/strain curve, (b) Elongation at break graph, (c) Tensile strength graph, (d) Modulus of elasticity.

The tensile strength of TC fibers (526 MPa) has similar values to cotton (300 $600 \mathrm{MPa})$ or flax $(345-1035 \mathrm{MPa})$ or jute $(187-773 \mathrm{MPa})$, while their elonga- 
tions (2.25\%) are similar to those of jute or sisal in the literature [30] [31], but also to that of untreated TC (2.55\%) from the work of Senwitz et al., [2]. The Young's modulus of the fiber samples from TC $(12.4 \mathrm{GPa})$ is rather low compared to that of TC (53.4 - 59.8 GPa) routed between three and six weeks respectively [2]. Similar values show a stiffness comparable to that of cotton (5.50 $12.6 \mathrm{GPa})$ or jute (10 - 26.5 GPa) [31], (6.3 - 26 GPa) [22] and RC (2.3 - 17 GPa) [38]. All these mechanical properties $(\sigma, \mathrm{E}, \varepsilon)$ of TC fibers are still superior to those of NA fiber [39]. These fiber tensile results also support the $44.4 \%$ cellulose content obtained in the chemical composition. Also, many factors such as extraction methods, fiber morphology, climate, age (or maturity stage), different geographical area could influence these mechanical properties [31].

In the end, TC fibers are flexible compared to hemp and flax fibers as these have a low Young's modulus. The softer a fiber is, the lower its Young's modulus and therefore it finds applications in composites and textiles [1].

\section{Conclusion}

The bast fibers of Triumfetta cordifolia A.Rich., extracted by retting, have been characterized. The results reveal that the fiber consists of several elementary fibers with oval cross-sections. They have a density of $1.477 \mathrm{~g} / \mathrm{cm}^{3}$. Although the water absorption of these fibers is quite high, it can be improved by surface treatment of the fiber. The fiber consists of cellulose, hemicellulose, lignin, pectins and minerals. Its $44.4 \%$ cellulose content in particular gives it tensile properties similar to those of jute, flax and kenaf. This makes them suitable for the same applications. Moreover, in terms of mechanical properties, TC fiber has a relatively low tensile stress and high elongation at break compared to the same species in the literature. This difference could be justified by the different geographical location of fiber harvesting. This study also shows that the fiber can withstand the processing temperatures of the proposed composites without degradation. It is therefore suitable for the implementation of composites by thermocompression. This work has therefore confirmed that TC fibers are suitable for the reinforcement of composite materials. In perspective, this work will be complemented by surface treatments of TC fibers and then biocomposites will be manufactured with matrices of tannin resins and natural rubber latex reinforced with treated and untreated TC fibers.

\section{Acknowledgements}

Our thanks go to Jean-Bosco Saha Tchinda and Herman Assonfack Lekane of the Laboratory of Macromolecular Applied Chemistry Unit, Faculty of Sciences of the University of Yaoundé 1, for their availability and practical advice. The same goes for Stanislas Tido Tiwa of the African University of Science and Technology, Abuja-Nigeria for his great availability and numerous services.

\section{Conflicts of Interest}

The authors declare no conflicts of interest regarding the publication of this paper. 


\section{References}

[1] Sauvageon, T. (2017) Caractérisation et valorisation de fibres de chanvre issues de sols et de matériels délaissés: cas du traitement par explosion à la vapeur (Doctoral dissertation).

[2] Senwitz, C., Kempe, A., Neinhuis, C., Mandombe, J.L., Branquima, M.F. and Lautenschläger, T. (2016) Almost Forgotten Resources-Biomechanical Properties of Traditionally Used Bast Fibers from Northern Angola. BioResources, 11, 7595-7607. https://doi.org/10.15376/biores.11.3.7595-7607

[3] Poletto, M., Zattera, A.J., Forte, M.M.C. and Santana, R.M.C. (2012) Thermal Decomposition of Wood: Influence of Wood Components and Cellulose Crystallite Size. Bioresource Technology, 109, 148-153. https://doi.org/10.1016/j.biortech.2011.11.122

[4] Tserki, V., Matzinos, P., Kokkou, S. and Panayiotou, C. (2005) Novel Biodegradable Composites Based on Treated Lignocellulosic Waste Flour as Filler. Part I. Surface Chemical Modification and Characterization of Waste Flour. Composites Part A: Applied Science and Manufacturing, 36, 965-974. https://doi.org/10.1016/j.compositesa.2004.11.010

[5] Poletto, M., Zattera, A.J. and Santana, R.M.C. (2012) Thermal Decomposition of Wood: Kinetics and Degradation Mechanisms. Bioresource Technology, 126, 7-12. https://doi.org/10.1016/j.biortech.2012.08.133

[6] Dumont, P., Orgéas, L., Martoia, F., Budtova, T. and Vincent, M. (2017) Mise en oeuvre des composites à fibres lignocellulosiques.

[7] Ouajai, S. and Shanks, R.A. (2005) Composition, Structure and Thermal Degradation of Hemp Cellulose after Chemical Treatments. Polymer Degradation and Stability, 89, 327-335. https://doi.org/10.1016/j.polymdegradstab.2005.01.016

[8] Bourmaud, A. and Balay, C. (2010) Effects of Thermo Mechanical Processing on the Mechanical Properties of Biocomposites Flax Fibers Evaluated by Nanoindentation. Polymer Degradation and Stability, 95, 1488-1494. https://doi.org/10.1016/j.polymdegradstab.2010.06.022

[9] Alix, S. (2014) Développement de matériaux composites fiberux hautes performances à matrice bio-sourcée. Thèse de doctorat, Université de Lorraine, Lorraine.

[10] Brink, M. and Achigan-Dako, E.G. (2012) Plantes à fibers (Vol. 16) PROTA.

[11] Lowell, S., et al. (2004) Characterization of Porous Solids and Powders: Surface Area, Pore Size and Density. Springer, Berlin, 327-330.

https://doi.org/10.1007/978-1-4020-2303-3

[12] Sreedhara, S.S. and Tata, N.R. (2013) A Novel Method for Measurement of Porosity in Nanofiber Mat Using Pycnometer in Filtration. Journal of Engineered Fibers and Fabrics, 8, 155892501300800408. https://doi.org/10.1177/155892501300800408

[13] Nadlene, R., Sapuan, S.M., Jawaid, M., Ishak, M.R. and Yusriah, L. (2015) Material Characterization of Roselle Fiber (Hibiscus sabdariffa L.) as Potential Reinforcement Material for Polymer Composites. Fibers \& Textiles in Eastern Europe, 6, 23-30. https://doi.org/10.5604/12303666.1167413

[14] Tahri, I., Ziegler-Devin, I., Ruelle, J., Segovia, C. and Brosse, N. (2016) Extraction and Characterization of Fibers from Palm Tree. BioResources, 11, 7016-7025. https://doi.org/10.15376/biores.11.3.7016-7025

[15] De Rosa, I.M., Kenny, J.M., Puglia, D., Santulli, C. and Sarasini, F. (2010) Morphological, Thermal and Mechanical Characterization of Okra (Abelmoschus esculentus) Fibers as Potential Reinforcement in Polymer Composites. Composites Science 
and Technology, 70, 116-122. https://doi.org/10.1016/j.compscitech.2009.09.013

[16] Amandine, C., Olivier, G., Frédéric, J. and Sylvain, F. (2014) Utilisation de la spectrométrie infrarouge pour une quantification rapide du taux d'humidité dans des fibers végétales. Revue des composites et des matériaux avancés, Lavoisier, 24, 81-95. https://doi.org/10.3166/rcma.24.81-95

[17] Célino, A., Gonçalves, O., Jacquemin, F. and Fréour, S. (2014a) Qualitative and Quantitative Assessment of Water Sorption in Natural Fibres Using ATR-FTIR Spectroscopy. Carbohydrate Polymers, 101, 163-170.

[18] Thuault, A., Eve, S., Blond, D., Breard, J. and Gomina, M. (2014) Effects of the Hygrothermal Environment on the Mechanical Properties of Flax Fibers. Journal of Composite Materials, 48, 1699-1707. https://doi.org/10.1177/0021998313490217

[19] Johar, N., Ahmad, I. and Dufresne, A. (2012) Extraction, Preparation and Characterization of Cellulose Fibers and Nanocrystals from Rice Husk. Industrial Crops and Products, 37, 93-99. https://doi.org/10.1016/j.indcrop.2011.12.016

[20] Dai, D. and Fan, M. (2011) Investigation of the Dislocation of Natural Fibers by Fourier-Transform Infrared Spectroscopy. Vibrational Spectroscopy, 55, 300-306. https://doi.org/10.1016/j.vibspec.2010.12.009

[21] NagarajaGanesh, B., Ganeshan, P., Ramshankar, P. and Raja, K. (2019) Assessment of Natural Cellulosic Fibers Derived from Senna auriculata for Making Light Weight Industrial Biocomposites. Industrial Crops and Products, 139, Article ID: 111546. https://doi.org/10.1016/j.indcrop.2019.111546

[22] Sango, T., Yona, A.M.C., Duchatel, L., Marin, A., Ndikontar, M.K., Joly, N. and Lefebvre, J.M. (2018) Step-Wise Multi-Scale Deconstruction of Banana Pseudo-Stem (Musa acuminata) Biomass and Morpho-Mechanical Characterization of Extracted Long Fibres for Sustainable Applications. Industrial Crops and Products, 122, 657-668. https://doi.org/10.1016/j.indcrop.2018.06.050

[23] Célino, A., Gonçalves, O., Jacquemin, F. and Fréour, S. (2014) Qualitative and Quantitative Assessment of Water Sorption in Natural Fibers Using ATR-FTIR Spectroscopy. Carbohydrate Polymers, 101, 163-170. https://doi.org/10.1016/j.carbpol.2013.09.023

[24] Moonart, U. and Utara, S. (2019) Effect of Surface Treatments and Filler Loading on the Properties of Hemp Fiber/Natural Rubber Composites. Cellulose, 26, 7271-7295. https://doi.org/10.1007/s10570-019-02611-w

[25] Krishnaiah, P., Ratnam, C.T. and Manickam, S. (2017) Enhancements in Crystallinity, Thermal Stability, Tensile Modulus and Strength of Sisal Fibres and Their PP Composites Induced by the Synergistic Effects of Alkali and High Intensity Ultrasound (HIU) Treatments. Ultrasonics Sonochemistry, 34, 729-742. https://doi.org/10.1016/j.ultsonch.2016.07.008

[26] Faruk, O., Bledzki, A.K., Fink, H.P. and Sain, M. (2012) Biocomposites Reinforced with Natural Fibers: 2000-2010. Progress in Polymer Science, 37, 1552-1596. https://doi.org/10.1016/j.progpolymsci.2012.04.003

[27] Tahir, Md.P., Ahmed, A.B., SifulAzry, S.O.A. and Ahmed, Z. (2011) Retting Process of Some Bast Plant Fibers and Its Effect on Fiber Quality: A Review. BioResources, 6, 5260-5281.

[28] Pereira, P.H.F., Rosa, M.D.F., Cioffi, M.O.H., Benini, K.C.C.D.C., Milanese, A.C., Voorwald, H.J.C. and Mulinari, D.R. (2015) Vegetal Fibers in Polymeric Composites: A Review. Polímeros, 25, 9-22. https://doi.org/10.1590/0104-1428.1722

[29] Li, X., Tabil, L.G. and Panigrahi, S. (2007) Chemical Treatments of Natural Fiber for Use in Natural Fiber-Reinforced Composites: A Review. Journal of Polymers and 
the Environment, 15, 25-33. https://doi.org/10.1007/s10924-006-0042-3

[30] Gurunathan, T., Mohanty, S. and Nayak, S.K. (2015) A Review of the Recent Developments in Biocomposites Based on Natural Fibres and Their Application Perspectives. Composites Part A: Applied Science and Manufacturing, 77, 1-25. https://doi.org/10.1016/j.compositesa.2015.06.007

[31] Jeyapragash, R., Srinivasan, V. and Sathiyamurthy, S. (2020) Mechanical Properties of Natural Fiber/Particulate Reinforced Epoxy Composites: A Review of the Literature. Materials Today: Proceedings, 22, 1223-1227.

https://doi.org/10.1016/j.matpr.2019.12.146

[32] Yao, F., Wu, Q., Lei, Y., Guo, W. and Xu, Y. (2008) Thermal Decomposition Kinetics of Natural Fibers: Activation Energy with Dynamic Thermogravimetric Analysis. Polymer Degradation and Stability, 93, 90-98. https://doi.org/10.1016/j.polymdegradstab.2007.10.012

[33] Teixeira, F.P., Gomes, O.D.F.M. and de Andrade Silva, F. (2019) Degradation Mechanisms of Curaua, Hemp, and Sisal Fibers Exposed to Elevated Temperatures. BioResources, 14, 1494-1511.

[34] Fan, M., Dai, D. and Huang, B. (2012) Fourier Transform Infrared Spectroscopy for Natural Fibers. Fourier Transform-Materials Analysis, 3, 45-68.

https://doi.org/10.5772/35482

[35] Sedan, D. (2007) Etude des interactions physico-chimiques aux interfaces fibers de chanvre/ciment: Influence sur les propriétés mécaniques du composite. Doctoral Dissertation, Limoges. https://doi.org/10.1051/mattech:2007038

[36] Ornaghi, H.L., Poletto, M., Zattera, A.J. and Amico, S.C. (2014) Correlation of the Thermal Stability and the Decomposition Kinetics of Six Different Vegetal Fibers. Cellulose, 21, 177-188. https://doi.org/10.1007/s10570-013-0094-1

[37] Deepa, B., Abraham, E., Cherian, B.M., Bismarck, A., Blaker, J.J., Pothan, L.A. and Kottaisamy, M. (2011) Structure, Morphology and Thermal Characteristics of Banana Nano Fibers Obtained by Steam Explosion. Bioresource Technology, 102, 1988-1997. https://doi.org/10.1016/j.biortech.2010.09.030

[38] Ntenga, R. (2007) Modélisation multi-échelle et caractérisation de l'anisotropie élastique de fibers végétales pour le renforcement de matériaux composites (Doctoral Dissertation).

[39] Ateba, A., Evoung, Y.S.N., Ebanda, F.B., Laynde, T. and Tchinda, J.S. (2019) Morphological and Mechanical Characteristics of Neuropeltis Acuminatas (na) Fibers. International Journal of Academic Research and Reflection, 7, 25-31. 